Dr. Copeland's party-has chosen a site up the hill behind the town some distance from the jetty.

Elaborate arrangements have been made for the observation of shadow bands, two walls, E. and W. and N. and S., composed of first-class volley targets $16 \times 6 \mathrm{ft}$., having been erected on a level space which has been whitewashed.

Six discs have been set up on spars, and most careful drills have taken place. I have been quite astonished at the exact reproduction of all the features of a dummy corona set up on each occasion.

It appears that the east wind is the best for us, and it is blowing now ; a cloudy morning generally is followed by a cloudless sky in the afternoon. The weather chances are good, but they are not perfect.

NORMAN LOCKYER.

\section{FIFTY YEARS OF GEOLOGICAL SURVEY IN INDIA.}

THOUGH the Honourable East India Company had showed their interest in the advancement of geological science by the appointment, so long ago as I8I8, of a geologist to the Great Trigonometrical Survey, it is but fifty years since the first "Report of the Geological Survey of India for I848-49," by Dr. John McClelland, was published. In $185 \mathrm{I}$ Dr. McClelland was relieved by Dr. Thos. Oldham, who, on his arrival in Calcutta, found the Geological Survey represented in the capital of India by a room, a box and a messenger. One assistant, Mr. W. Theobald, was already in the employment of the Company, and during the following five years seven assistants were appointed, of whom but Mr. H. B. Medlicott and Dr. W. T. Blanford, names cut deep in the record of Indian geology, survive.

It was not, however, till 1856 that the Geological Survey was established as a regularly organised service, with a sanctioned establishment of superintendent (now styled director), fifteen graded assistants and a palcontologist. In spite of the increased area over which British rule extends, the establishment sanctioned in 1856 remained the same, with some minor, temporary changes, and an alteration of nomenclature, till 1892 , when, instead of an increase, the permanent staff was reduced by three, and to compensate for this reduction arrangements were made for the employment of two "specialists" for terms of years, who were expected to devote their services more especially to economic geology. From one cause and another, this scheme has not received a full trial yet, and it is only during the present year that the full sanctioned staff is at work. The experiments so far made in the temporary employment of assistance to the Geological Survey, for the special purpose of economic work, cannot be regarded as successful, and the result of the present trial will be watched with interest, as it is likely to have great influence in the shaping of the future course and policy of the Survey.

The concrete results of less than half a century's work with this inadequate staff are a geological map of nearly the whole of India proper, which is accurate as regards its main features for this large area, and as regards details for a large proportion of it ; and a considerable acquaintance, largely accompanied by maps, with the mountainous country to the north-west and north, and of the countries to the east, which are included in the Indian Empire. The published results are contained in thirty volumes of the "Records," twenty-nine of the "Memoirs" and twenty volumes, not counting those only partly published, of the "Palceontologia Indica."

Besides this collection of separate memoirs there was prepared, with the approval and sanction of the Government of India, a "Manual of the Geology of India," in two volumes, by Messrs. H. B. Medlicott and W. T.
Blanford, published in 1879 , to which were subsequently added a volume on the "Economic Geology," by the late Dr. Valentine Ball, and one on the "Mineralogy," by Mr. F. R. Mallet. These volumes contained not only much information collected by the Survey, which it had not been possible to publish previously, but for the first time, by collecting scattered information into one general review, made the geology of India generally accessible and intelligible. The need for, and value of, these volumes is shown by the fact that they soon went out of print, and in 1894 a revised version of the first two volumes was issued. The progress of the Survey in the period intervening between these two issues had been so great that a totally different scheme could be adopted, and instead of the series of separate descriptions of isolated areas, which was to a large extent inevitable in I879, it was possible to treat the geology of India as an harmonious whole in 1894 . A re-issue of the third volume of the original edition, the volume on "Economic Geology," has also been commenced, but though nominally a re-issue, it is, even more than in the case of the stratigraphical and structural geology, a new book, being different in scope and in aims, and containing no part of the original work.

The results of the Geological Survey, apart from its publications, are to be looked for both in India and out of it. In India, in the economic development of the Empire; and out of India, in the influence they have had on the advancement of geological science. The former of these is naturally that to which the Adminis. tration attaches the greater importance, and in this connection the existence of the Survey is amply justified in the fact that two of the coal-fields, which yield an important part of the coal-supply of India, were discovered and explored by the Geological Survey. Singarenni, surveyed by Dr. W. King, and Umaria, by Mr. T. W. Hughes, have, from their geographical position, a much greater importance than would appear merely from a numerical statement of the number of tons of coal raised in them, for they serve to supply a large area with cheap fuel which would otherwise be deprived of that advantage. These two fields in themselves would justify the existence of the Survey, from an economic point of view, apart from other benefits; but besides this the existence of a band of trained advisers, and of the observations accumulated by them, has frequently been instrumental in preventing the useless expenditure of large sums of money, and in this way alone the Survey has rendered an ample return for its maintenance.

Though the Administration is naturally most interested in the economic aspects of the work of the Geological Survey, there has never been any attempt to convert it into a mere prospecting or mining department. The Government of India has always recognised purely scientific work as an important duty of the Survey, and regarded the advancement of science not only as a thing to be desired and encouraged on its own account, but as furthering and rendering more valuable the economic results of the Survey, by improving the instrument with which it works. It is this portion of the work of the Survey which is of the greater interest outside India, and more especially to the readers of NATURE.

First among the results which have influenced the course of geological science may be placed the recognition of the importance of deposits formed on land, in which Indian survey took an early and important part. It was shown that the Gangetic alluvium, formerly looked upon as a marine deposit, was, as regards its upper layers at least, a land deposit; it was shown that the great series of sandstones and conglomerates of which the foot-hills of the Himalayas are composed were formed, not in the sea, but on land, by rivers which were the ancestors of those now draining the Himalayas; the great Gondwana system was shown to be exclusively a dry land deposit,

NO. I 596, vOL. 62] 
and later the same origin was attributed to the great Vindhyan system.

In the next place we have the recognition of the Permian glacial epoch. The first description of these beds was published in the Memoirs of the Geological Survey in 1856 , and their glacial origin proclaimed in I 875 by the late Mr. H. F. Blanford. Though the idea of glaciation in Permian times and in what are now low latitudes has met with great opposition, it has gradually made progress, and it is now generally recognised that the Permian boulder-beds of India, though extending inte regions that are now within the tropics, are relics of a bygone glacial epoch. In Africa, the glacial origin of similar beds has been accepted by more than one observer; and in Australia-where the traces of glacial action in the marine Permian or Permo-Carboniferous beds, below the principal coal-measures, was first recognised by a member of the Indian Geological Survey who had been deputed by the Indian Government to study the Australian coal-measures - the existence of glacial action on a large scale has been fully confirmed by workers in that country. In South America, too, it seems that there are similar beds, of apparently the same age, and the evidence of this widespread glacial epoch, more remarkable in many ways even than the post-Tertiary extension of glaciation, must be reckoned with in any speculations attempting to account for the great climatic changes of which the past sediments bear witness.

The labours of the Indian Geological Survey have had important results in geological science in other minor points, too numerous to detail in the limited space of an article, but a mention of the great earthquake of I 897 cannot be omitted. This earthquake was the greatest of which there is historic record, exceeding the great Lisbon earthquake of 1755 ; but even before this was known the Indian Government had ordered the Survey to make a complete scientific investigation of it. Being the greatest earthquake of which there is historic record, the visible effects were on an unprecedented scale, and its investigation has consequently yielded results which must be taken into account in all future seismological research. Nor must mention be omitted of one of the most recent suggestions, which appears likely to be fruitful of results, made in 1898 by $\mathrm{Mr}$. T. H. Holland, that much of the decomposition, and more especially hydration, of the minerals composing igneous rocks was submarine, and that the undecomposed state of similar rocks, even of perishable minerals like olivine and nepheline, in certain regions, is due to these being ancient land-areas which have not been submerged beneath the sea since a remote geological period.

Such, briefly stated, is the record of the Geological Survey of India, a record which reflects credit on all who have been concerned in the making of it. Yet it must not be forgotten that credit is due also to the Civil Administration of India, which has not only maintained the staff by whom the record has been made, but has given the further pecuniary assistance, modest in amount but steadily continued, which has enabled the Survey to form a museum fully illustrating the geology of India in all its branches, to establish a well-equipped laboratory, and to collect a library which, as a geological working library, is probably unsurpassed by any and equalled by few.

\section{NOTES}

M. Darboux, Dean of the Faculty of Sciences of Paris, has been elected permanent secretary of the Paris Academy of Sciences, in succession to the late M. Joseph Bertrand. Prof. J. Willard Gibbs, professor of mathematical physics in Yule University, has been elected a correspondant of the Academy in the section of mechanics. Prof. J. Chatin, assistant professor of histology at the Sorbonne, has been elected a member of the section of anatomy of the Academy, in succession to the late M. Blanchard.

THE recommendations of the international conference which recently met in London to determine the steps which might usefully be taken for the preservation of wild animals, birds and fish in South Africa, have now been published as a Parliamentary Paper. The zone within which it is proposed to apply the provisions of the Convention is bounded on the north by the 2oth parallel of north latitude, on the west by the Atlantic Ocean, on the east by the Red Sea and by the Indian Ocean, on the south by a line following the northern boundary of the German possessions in Suth-Western Africa, from its western extremity to its junction with the River Zambesi, and thence running along the right bank of that river as far as the Indian Ocean. To preserve the various forms of animal life existing in a wild state within this zone, it is proposed to prohibit the hunting and destruction of certain animals, especially females when accompanied by their young or capable of being otherwise recognised, of which the protection, whether owing to their usefulness or to their rarity and threatened extermination, may be considered necessary by each local government. The establishment, as far as it is possible, of reserves within which it shall be unlawful to hunt, capture or kill any bird or other wild animal except those specially exempted from protection by the local authorities, is recommended, and also of close seasons with a view to facilitate the rearing of young. It is proposed to put export duties on the hides and skins of giraffes, antelopes, zebras, rhinoceroses and hippopotami, on rhinoceroses and antelope horns, and on hippopotamus tusks, and to prohibit the hunting or killing of young elephants. Measures are to be taken for ensuring the protection of the eggs of ostriches, and for the destruction of the eggs of crocodiles, of those of poisonous snakes, and of those of pythons. It is, however, understood that some of the principles laid down may be relaxed, either in order to permit the collection of specimens for museums or zoological gardens, or for any other scientific purpose.

Prof. J. PERry, F.R.S., has been elected president of the Institution of Electrical Engineers for the session 1900-190r.

MR. BORCHGREVINK, who recently returned from his explorations in the Antarctic, will, it is expected, give a lecture before the Royal Geographical Society on June 18.

The American Academy of Arts and Scienses has decided to award the Rumford medal to Prof. Carl Barus, of Brown University, for his researches in heat.

WE learn from Science that the Committee of Coinage, Weights and Measures of the U.S. House of Representatives has unanimously agreed to report as an amendment to the Sundry Civil Bill the measure establishing a United States Standardising Bureau, referred to in NATURE of May I7 (p. 6I).

WE regret that a part of the edition of last week's NATURE appeared without the announcement that the names of Dr. D. Gill, F.R.S., and Dr. T. E. Thorpe, F.R.S., were included in the list of Birthday Honours. The former has been promoted to the rank of K.C.B., and the latter has been created a C.B.

THE third Liverpool expedition for the study of tropical diseases, referred to last week, will start in the first week in July. The members of the expedition are Drs. Durham and Walter Myers. The object of the expedition is to study yellow fever, malaria and dysentery.

AN excursion to Malvern and district has been arranged by the Geologists' Association for Whitsuntide. The director will be Prof. T. T. Groom, and during the stay at Malvern, from Saturday, June 2, to Tuesday, June 5, a number of interesting geological sections and structures will be examined.

NO. I 596, VOL. 62] 